from radium are shorter in wave-length than those that emerge from any $X$-ray tube at present in use.

It is possible that in a few years time the new discoveries of physics, the neutron and artificial radioactivity, will find a place in radiation therapy. Already, in the United States, neutron beams are available of sufficientlv high intensity to produce strong biological effects; their mode of action must differ in many respects from the radiations with which radiologists are familiar. Also it is now possible to obtain gamma-rays from artificial radioactive substances with energies far in excess of anything which radium emits. Radio-sodium, for example, disintegrates with emission of gammarays having energies in excess of 3 million volts. This substance has already been produced in weighable quantities; if it should prove possible to make it cheaply in bulk, it could be inserted daily into a radium unit of conventional design, and used for treatment in place of radium. All the knowledge which has been accumulated for radium beam therapy in the past could be brought to bear on the powerful new radiation.

In the meantime, it is of the greatest importance that there should be competent comparisons of the effects of radium and X-ray treatment, in which therapists, pathologists, biologists and physicists may make a thorough study of the results produced in living tissue, whether healthy or diseased, and explore to the full the new methods which the advance of physics is making available.

\title{
Biological Work of the Oxford University Expedition to North-East Land, I935-36
}

\author{
By D. B. Keith
}

$\mathrm{N}^{\mathrm{O}}$ ORTH-EAST LAND is the second largest island of the Spitsbergen archipelago and lies astride the parallel of $80^{\circ} \mathrm{N}$. Until a few years ago, it remained virtually an unknown land of evil repute. It was thought to lie outside the influence of the Gulf Stream and therefore to suffer from a far severer climate than the rest of Spitsbergen. The Oxford University Expedition, under the leadership of A. R. Glen, was the first expedition to winter in the country, and besides the radio research work, glaciology, survey and other activities of the expedition (see Nature, Jan. 2, p. 10), biological work was carried out through the year.

It may be said at the start that the animal life of North-East Land is incredibly meagre, and the reason for the great difference between there and the rest of Spitsbergen is the very much colder summer conditions prevailing on the island. The winter, too, is severer, but this has not the same effect on the animal life; but when it is realized that the temperature in the summer months very rarely rises above $40^{\circ} \mathrm{F}$., that snow storms are liable to occur at any time and that strong winds are almost continuous, it is not hard to see the reason for the paucity of animal life. It is probably not quite true to say that the Gulf Stream has no effect on North-East Land, for it now seems almost certain that the north-western coast does come under its influence, but its effect here is so small that the air temperature is invariably low and the weather usually windy and misty.
The difference between North-East Land and even the nearest areas of New Friesland is at once apparent in the vegetation. In North-East Land, the vegetation type most common is so open that it seems impossible to believe that biotic factors have played any part in its formation, whilst even in such areas as Treurenberg Bay and Lomme Bay, close plant communities are fairly extensive. In fact, the only areas in North-East Land where anything approaching close formations are to be found are in such places as the scree slopes below bird cliffs, areas (usually small islands) where colonies of eiders or terns are nesting, or, in a smaller way, round old nests of eiders, brent geese or glaucous gulls. Much of my biological work this summer was carried out in Murchison Bay, a large bay on the western coast, thickly dotted with islands, but one of which almost all the surrounding country is composed of dolomite. The sterility of the vegetation in such an area defies description. The rock weathers into fragments which are found covering great areas and lying loosely over the surface, entirely prohibiting any plant growth. Here and there a few specimens of Saxifraga oppositifolia or Papaver radicatum may have been able to take root; but it is almost true to say that the only places where plants are found are those where there has been manuring in some form or another.

My main work was a study of the birds, and here again the same may be said with regard to 
the paucity both of species and individuals. So far, only twenty-seven species of birds have been recorded from North-East Land, and of these only

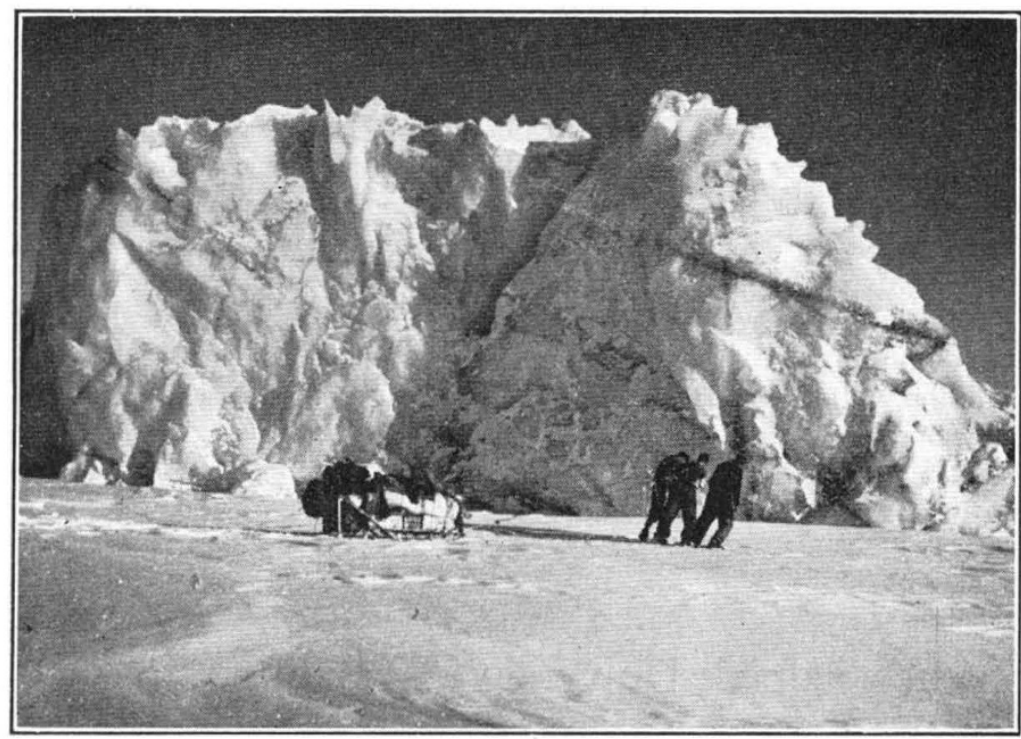

Fig. 1.

SLedging Down equipment for the biological station in Murchison Bay.

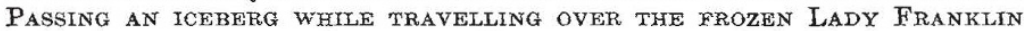
BAY.

some sixteen breed regularly. As the base hut was built on a small area of level ground at the foot of a wall of towering basaltic cliffs, which in the summer were tenanted by nesting fulmars and Mandt's guillemots, I had a good opportunity for watching the arrival of these birds in the spring, which was of particular interest for the fact that the guillemots used at first to spend only certain hours each day at the eliffs.

The first sign of life in 1936 , apart from a few solitary bears and one or two reindeer, was when a fulmar was seen flying silently along the face of the cliff in the half jight of February 15, more than a week before the sun rose. Nothing else was seen until March 10, when four Mandt's guillemots visited the cliffs. This was the beginning of a long series of visits, for the guillemots arrived every night and left again early in the morning. As the month progressed they spent longer times at the cliffs, but these were always deserted in the afternoons. By March 19 the numbers had increased and the birds were staying until about 11 a.m. By
March 31 they were arriving at 1 or 2 a.m., but leaving again at about 7 a.m. Gradually they began to arrive earlier and stay later. This curious habit of deserting the cliffs in the afternoon was not followed by the fulmars, which began to arrive after April 7. In the night and morning the cliffs were shared by guillemots and fulmars, but in the afternoons the latter were in solitary posses. sion; and this continued until the end of April, when guillemots began to stay at the cliffs throughout the day.

The first nest I found was one of a red-throated diver, which on June 21 contained one egg (Fig. 3). From that date the divers and eiders began to nest, but it at once became evident that though the former were nesting in normal numbers, that is, there was a breeding pair on almost every freshwater tarn of suitable size, only a very small percentage of the ducks were breeding at all. This non-breeding, which this year was found in the case of the eider and brent geese, is a regular feature of arctic bird life and one of great interest. From work done all over the

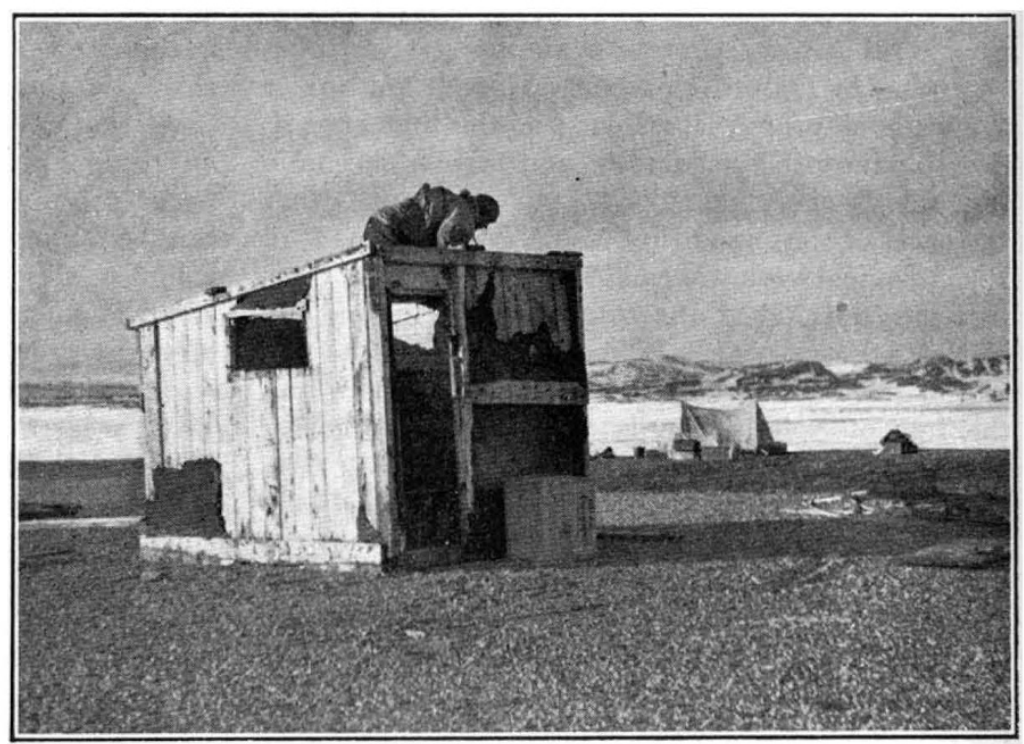

Fig. 2.

The biologrcal station on RUSSian Island IN MURChison Bay occupied By KeITH and Godfrey from April until JULy, 1936.

Arctic, notably in Greenland and Spitsbergen, it seems fairly certain that every fourth year or so certain species of birds are affected, and of these 
species many less than the normal percentages are found breeding. The birds most commonly found to be affected are the ducks, geese and divers, but in North-East Land the divers were breeding in normal numbers.

It is as yet difficult to account for this phenomenon. Many and varied suggestions have from time to time been put forward. It would appear that it must bear some relation to changing climatic conditions, as these must be assumed to be the only variable factor in the environment of the birds until some variation at present unknown is shown to take place in their marine food supply. But this leaves us with the difficulty of explaining the regularity of the occurrence of the non-breeding years by climatic changes which have not yet been shown to follow the necessary cycle of 3-4 years. The late melting of the sea-ice and disappearance of the snow from the land might in some cases give an explanation, but this cannot find universal acceptance because in a non-breeding year the birds that do breed do not usually begin to nest any later than usual. Again, such a condition could scarcely affect the ducks without to some extent also affecting the red-throated divers. It is also impossible to suppose some general factor which affects reproduction throughout the Arctic, because species such as the waders and passerines have never yet been shown to be affected in this way. During the earlier part of the summer, I examined the gonads of many eiders, and the general result was that the ovaries were scarcely enlarged at all, but that the testes of the drakes were developed to the normal size of a breeding bird. It would be unwise as yet to argue from this one case, but if similar observations are carried out elsewhere and the same result found, the reason for the non-breeding will have to be found in some factor which affects the sexual development of the female and not of the male. It was noticeable throughout the first part of the summer how much more sexually excited the drakes were than the ducks.

Even in normal years North-East Land has a large non-breeding population, but this is entirely different from that which I have been describing above. The island lies at the extremity of the breeding area of most birds visiting it, and it seems to a large extent to be populated by birds which were bred elsewhere and have had to move out from the more favoured areas of their range to this uninviting marginal territory. Only by this supposition can I account for the large nonbreeding population which seems to be a normal feature in every species. It is difficult to estimate non-breeding percentages among eliff nesting species, but it was abundantly clear that large

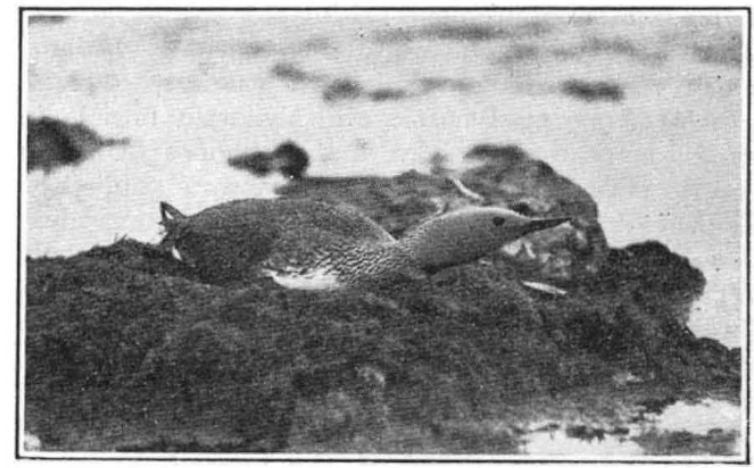

Fig. 3.

RED-THROATED DIVER ON NEST.

numbers of non-breeding Arctic skuas, terns, grey phalarope, purple sandpipers and snow buntings were a normal feature of the ornithology of NorthEast Land. It was also clear that the numbers of each species which were breeding were quite inadequate to maintain the status of that species with anything like a normal rate of mortality.

This question of non-breeding both in normal and abnormal years is one of the most interesting confronting the ornithologist visiting North-East Land, and I have but touched on it here. Another problem is that of distribution. North-East Land is an excellent field for this and other inquiries, as the factors which have to be considered can be so much more easily seen there than in more temperate regions with their more complex bird communities.

\section{Obituary Notices}

Sir Grafton Elliot Smith, F.R.S.

W'ITH deep regret we record the death of Sir pologist and former professor of anatomy in the University of London (University College), which took place at Broadstairs on January 1 after a pro. longed period of ill-health, at the age of sixty-five years.
Grafton Elliot Smith was born on August 15, 1871, at Grafton, New South Wales, and was educated at the Universities of Sydney, where he obtained the degree of doctor of medicine in 1895, and Cambridge, where he was a fellow of St. John's College, on which foundation he afterwards became an honorary fellow. On obtaining his degree in medicine, he devoted himself especially to the study of the comparative 